УДК 378.147

DOI:

Світлана Давидова, аспірант кафедри педагогіки і педагогічної майстерності Мелітопольського державного педагогічного університету імені Богдана Хмельницького

\title{
ПРОЕКТНА ДІЯЛЬНІСТЬ ЯК ЗАСІБ ФОРМУВАННЯ ПРОФЕСІЙНОЇ КОМПЕТЕНТНОСТІ МАЙБУТНІХ УЧИТЕЛІВ ОБРАЗОТВОРЧОГО МИСТЕЦТВА
}

У статті автор розгорнуто аналізуе сутність понять “проект”, “проектування”, “проектна технологія”, “проектна діяльність", “творча проектна діяльність” у історичному аспекті та педагогічній практиці останніх років на прикладі окремих спеціальностей. Обтрунтовується сучасна актуалізація методу проектів у підготовиі педагогічних кадрів, професійна діяльність яких має творчі витоки, що змушує під новим кутом подивитись на проектну діяльність як засіб формування професійної компетентності майбутніх учителів образотворчого мистецтвва у системі вищої педагогічної освіти.

Ключові слова: проект; творчий проект; проектна технологія; проектна діяльність; творча проектна діяльність; учитель образотворчого мистецтва.

Jim. 15.

Svitlana Davydova, Postgraduate Student of the Pedagogy and Pedagogical Skill Department Melitopol Bohdan Khmelnitskiy State Pedagogical University

\section{THE PROJECT ACTIVITIES AS A MEANS OF FORMATION OF PROFESSIONAL COMPETENCE OF FUTURE TEACHER OF FINE ARTS}

This article presents the contemporary trends of education system updating and reforming, which are associated with changes in the competence approach in the training of specialists and teachers of fine arts. The historical development of the project method and its application in the training of specialists and teachers is revealed. The author structurally describes the stages of the project activities, which correspond to the general components of the project and are described in the scientific pedagogic literature.

The author analyzes a variety of examples of project activities application in the training of specialists of different fields and teachers. The actualization of the projects method in the modern training of pedagogical stuff, whose professional activity has creative origin, makes it possible to look at the project activities as at means of forming the professional competence of future teachers of fine arts in the system of higher pedagogical education. It is emphasized that nowadays, the project training is actual and progressive, as it creates conditions for the disclosure of the students' creative potential, increases their motivation, and helps to obtain the necessary skills and knowledge, develops their intellectual abilities and forms the professional competence as a competitive specialist of the XXI century. The project activities will ensure the acquisition of professional socially relevant knowledge, skills and abilities that meet the current educational request and the paradigm of personalized learning, because this knowledge and skills allow young professionals to study throughout their lives and successfully pursue their professional activities. The project activities create not only the conditions for acquiring and working out certain knowledge and skills, but also a positive atmosphere during the training process itself. That is why, the project method will be effective in shaping the respect and goodwill of future teachers of fine arts in their profession, which is prerequisite for a modern teacher. On the basis of theoretical analysis, the author emphasizes that the project activities are effective in pedagogical practice as a means of forming the professional competence of future teachers of fine arts and require additional scientific research.

Keywords: a project; creative project; project technology; project activities; creative project activities; a teacher of fine arts.

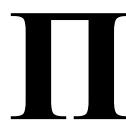

остановка проблеми. У сучасній українській освіті відбувається переосмислення компетентнісного підходу, ведуться дослідження щодо нових форм та методів формування професійної компетентності учителя, зокрема, це стосується учителів образотворчого мистецтва. Швидкоплинне життя висуває суспільний запит до учителів на виховання особистості нового покоління - творчої людини, здатної самостійно мислити і приймати рішення, віднаходити оригінальні ідеї та креативні рішення, що знайшло своє відображення у концепції "Нової української школи”. У вищих навчальних закладах перед педагогами постає складне завдання - забезпечення фізичного, інтелектуального, соціального, духовного розвитку майбутніх учителів образотворчого мистецтва 3 набором необхідних професійних компетентностей. За даних обставин особливої актуальності набуває дослідження проектного навчання, що передбачає “занурення” майбутніх учителів образотворчого мистецтва у навчальний 


\section{ПРОЕКТНА ДІЯЛЬНІСТЬ ЯК ЗАСІБ ФОРМУВАННЯ ПРОФЕСІЙНОӤ КОМПЕТЕНТНОСТІ МАЙБУТНІХ УЧИТЕЛІВ ОБРАЗОТВОРЧОГО МИСТЕЦТВА}

процес, який вимагає використання теоретичних знань на практиці і креативного мислення для розв'язання певних задач, що формує нове розуміння здобутих у такому навчанні вмінь та навичок, - це дає змогу ефективно i цілеспрямовано формувати їх професійну компетентність.

Аналіз останніх досліджень і публікацій. Теоретичні засади проектної діяльності розкривають у своїх дослідженнях О. Безпалько, В. Гузєєва, Дж. Дьюї, В. Кілпатрик, О. Коберник, О. Косович, Л. Лук'янова Н. Матяш, В. Нечипоренко, I. Петрова, О. Пєхота, С. Полат, В. Радіонова, Ч. Річардс, Л. Савчеко, В. Слободченкова, О. Слободяник, С. Сисоєва, М. Уйсімбаєва, М. Цигулева, І. Шевченко, І. Шендрик та ін.

Актуальні проблеми організації проектної діяльності стали предметом дисертаційних досліджень останніх років: М. Елькін (формування професійної компетентності майбутнього вчителя географії засобами проектної діяльності), С. Ізбаш (проектна діяльність як фактор соціальнопрофесійної адаптації студентів педагогічного університету), М. Курач (теоретичні і методичні засади навчання художнього проектування майбутніх учителів технологій), М. Пелагейченко (підготовка майбутніх учителів трудового навчання до організації проектної діяльності учнів основної школи), О. Зосименко (організація проектної діяльності майбугніх педагогів у процесі вивчення педагогічних дисциплін) та інших.

Зміст і значення проектної діяльності розглянуто у публікаціях О. Аліксійчук, А. Вдовиченко, А. Касперського, О. Коберника, В. Сидоренка, М. Ступницької, А. Терещука, Л. Хоменко та інших науковців.

Метою статті $\epsilon$ теоретичний аналіз виникнення та розвитку проектної діяльності як засобу формування професійної компетентності майбутніх учителів образотворчого мистецтва.

Виклад основного матеріалу. Професійна компетентність учителя - це актуальна проблема сьогодення, що активно обговорюється у наукових колах; таке положення пов'язане із змінами в освітньому просторі. Компетентність учителя розглядається, як динамічна комбінація знань, умінь, навичок, способів мислення, поглядів, цінностей, інших особистих якостей, що визначає здатність особи успішно соціалізуватися, провадити професійну навчальну діяльність. Діяльність учителя має бути спрямована на забезпечення всебічного розвитку особистості шляхом навчання та виховання, які грунтуються на загальнолюдських цінностях та принципах науковості, полікультурності, світського характеру освіти, системності, інтегративності, єдності навчання і виховання, на засадах гуманізму, демократії, громадянської свідомості, взаємоповаги між націями і народами в інтересах людини, родини, суспільства, держави [4]. Такі обставини змушують переглянути підходи щодо підготовки учителів образотворчого мистецтва, це звертає нашу увагу на метод проектів, який активно вивчався науковцями і довів свою ефективність у навчанні певних фахівців, формуванні їх професійної компетентності. Метод проектів, в основі якого творчість є обов'язковою складовою, застосовувався у фаховій підготовці учителів технологій, географії, іноземних мов та інших, такі дослідження мали позитивні результати, що дає змогу зробити припущення: проектна діяльність буде ефективним засобом формування професійної компетентності майбутніх учителів образотворчого мистецтва. Дослідження 3 цього питання слід почати 3 теоретичного аспекту.

Сучасна проектна діяльність бере свій початок 3 методу проектів, який виник у США на початку XX століття. Педагог Дж. Дьюї на основі концепції американського прагматизму запропонував будувати навчальний процес на активній основі - цілеспрямована діяльність студентів направлена на отримання певного результату. Учень та послідовник Дж. Дьюї В. Кілпатрик доповнив та розробив цю ідею у “проектну систему навчання" (метод проектів). Студенти залучались до практичної діяльності спрямованої на опанування практичних навичок та більш глибокого розуміння теоретичних знань. Метод проектів активно почали використовувати у навчанні іноземній мові у США та Європі з 1980 року. В історичній ретроспективі були виділені дві моделі методу проектів, що є актуальними і в сучасній педагогічній практиці. Першу модель розробив та запропонував К. Вудворт, який розумів суть проекту як первинне вивчення матеріалу, набуття знань і навичок, що будуть використовуватись у проектуванні. Друга модель, що була розроблена пізніше, належить Ч. Річардсу і передбачає “занурення” у поставлену проблему та грунтовне іiі вивчення - здобуття необхідних знань у процесі виконання проекту самостійними науковими пошуками. У вітчизняній практиці метод проектів використовується з 1990 року.

Л. Савченко відзначила позитивні аспекти методу проектів: він створює умови, за яких студент може самостійно здобувати знання чи застосовувати придбані раніше, причому замість дій за зразком в основному виступають пошукові й дослідницькі дії. Акцент робиться на творчий 
розвиток особистості. Студент повинен не тільки засвоїти необхідні знання й уміння, а й навчитися шукати і знаходити об'єкти для їх практичного застосування [11].

У нашому дослідженні необхідно відзначити творче проектування, яке 3'явилось у ХХІ столітті i має безпосереднє відношення до підготовки фахівців творчих спеціальностей і учителів технологій. 3 даного питання М. Курач відзначає, що метод творчих навчальних проектів орієнтований на самостійну діяльність людини індивідуальну, парну, групову, яку вона виконує упродовж певного проміжку часу. Метод творчих проектів завжди спрямований на розв'язання певної проблеми та передбачає, з одного боку, використання сукупності різноманітних форм, методів і засобів навчання, а 3 іншого необхідність інтеграції знань, умінь та застосування знань 3 різних галузей: науки, техніки, технологій, творчих галузей. Також автор робить наголос на тому, що результати виконаних проектів мають бути “відчутними”, тобто мати конкретний кінцевий результат, готовий до використання в реальному житті, у творчих спеціальностях - це продукт творчого характеру $[8,42]$.

Самостійність у навчанні, яка $є$ незмінною складовою проектної діяльністі та обов'язковою частиною сучасної освіти, забезпечує зосередженість студентів на виконанні основних навчальних завдань і передбачає: засвоєння навчального матеріалу; збільшення обсягу знань та їх якісне ускладнення; підвищення наявного рівня умінь та навичок; оволодіння раціональними методами та прийомами розумової праці; відкриття нових способів навчальної діяльності тощо $[13,37]$.

У контексті нашого дослідження метод проекту ми розуміємо як мотивацію студентів до надбання нових знань, умінь і навичок через участь у проекті (включення у певну діяльність) з чітко регламентованими часовими межами та описом продукту кінцевого результату. Процес виконання проекту активізує креативне мислення, творчі здібності та сприятиме самостійності студентів і формуванню професійної компетентності майбутніх учителів образотворчого мистецтва.

У педагогіці відомі різні типи навчальних проектів (творчі, ігрові, інформаційні, практикоорієнтовані, дослідницькі), але творчі проекти відрізняються від інших типів тим, що вони не мають чітко розробленої структури спільної діяльності групи учасників, для яких регламентовано кінцевий результат і форму його представлення - коллаж, картину, панно тощо.
Такі обставини дають змогувикладачу розкривати унікальний творчий потенціал кожної залученої до проекту людини і спрямовувати його на набуття нових знань, умінь та навичок через власне мислення.

Звернемо нашу увагу на інтерпретацію понять “проект”, “проектування”, “проектна технологія”, “проектна діяльність”.

Аналіз наукової вітчизняної та зарубіжної літератури свідчить про те, що поняття “проект" трактується вченими досить широко. Науковець Е. Гитман визначив “проект” як сукупність концептуальної і формальної моделі, пакет документів, який подає опис на предметній мові того, що і як повинно бути зроблено [2, 137]. О. Коберник дає більш вичерпне визначення, що наближене до сучасного розуміння: “проект" це прототип, ідеальний образ ймовірного або можливого об'єкту, стану; задум, план (projectio - кидання вперед), а проектування - як створення ідеального опису майбутнього об'єкта, що передує його реалізації; таким чином ми задаємо вектор розгляду педагогічного проектування як часткового випадку проектної практики в цілому $[7,13]$. О. Пометун конкретизував визначення проекту як задуму, плану, прообразу певного об'єкта [6, 99].

Окремим питанням проаналізуємо поняття “проектування”. Науковець О. Безпалько надав декілька визначень найбільш поширених дефініцій проектування: визначення версій чи варіантів розвитку або зміни певного явища чи об'єкту; конструювання варіантів оптимального майбутнього стану об'єкту; форма випереджального відображення і перетворення дійсності, спрямована на конструювання системи параметрів майбутнього матеріального об'єкту чи якісно нового його стану; прийняття рішень в умовах невизначеності $[1,5]$.

I. Шевченко розуміє проектування як нерегламентовану, творчу, поліфункціональну діяльність, що виконує аналітичну, прогностичну, конструктивну, організаційну і рефлексивну функції [14, 258]. Н. Яковлева конкретизувала поняття “проектування” і визначила його як процес створення проекту і його фіксацію в будьякій зовні вираженій формі. Цей термін має технічне звучання, але у сьогоденні він також використовується для позначення інтелектуальної діяльності зі створення проектів найрізноманітних типів $[15,14]$.

Науковець О. Слободяник підвела тлумачення проектування до сучасної лаконічної та стислої форми, що розглядається як основний механізм здійснення та розвитку інноваційної діяльності та 


\section{ПРОЕКТНА ДІЯЛЬНІСТЬ ЯК ЗАСІБ ФОРМУВАННЯ ПРОФЕСІЙНОЇ КОМПЕТЕНТНОСТІ МАЙБУТНІХ УЧИТЕЛІВ ОБРАЗОТВОРЧОГО МИСТЕЦТВА}

як вид творчості, який включає моделювання, прогнозування та аналітичне оцінювання [12]. Такого визначення ми будемо дотримуватися у наших наукових дослідженнях.

Звернемо нашу увагу на проектну технологію у педагогічній практиці. Л. Савченко стверджує, що проектна технологія передбачає наявність проблеми, що вимагає інтегрованих знань і дослідницького пошуку її вирішення. Результати запланованої діяльності повинні мати практичну, теоретичну, пізнавальну значимість. Головною складовою методує самостійність студента. Дуже важливою також є структуризація змістовної частини проекту із зазначенням поетапних результатів. Використання дослідницьких підходів у проекті є свого роду наріжним каменем технології. Причому послідовність цих методів можна поставити у такий ряд: визначення проблеми (визначення завдань, які випливають iз дослідження), висунення гіпотези вирішення завдань, обговорення методів дослідження, оформлення кінцевих результатів, аналіз одержаних даних, підбиття підсумків, коригування, висновки [11]. У науковій літературі зазначається щодо методу проектів як педагогічної технології, що вона передбачає сукупність дослідницьких, пошукових, проблемних методів, творчих за своєю сутністю.

Н. Любчак трактує проектну технологію як стимулювання інтересустудентів до певних проблем, що передбачають володіння визначеною сумою знань, та через проектнудіяльність, яка включає розв'язання однієї або низки проблем, показати практичне застосування надбаних знань від теорії до практики, гармонійно поєднуючи академічні знання 3 прагматичними, підтримуючи відповідний їх баланс на кожному етапі навчання $[9,145]$.

Таким чином, технологія проектування завжди пропонує розв'язання будь-якої проблеми, що передбачає, 3 одного боку, використання різноманітних методів, засобів навчання, а 3 іншого - інтегрування знань, умінь 3 різних галузей науки, техніки, творчості.

Для більш глибокого розуміння методу проектів необхідно розглянуги проектне навчання, де ми погоджуємося з С. Ізбаш, яка зазначає, що сутність цього навчання полягає у тому, що, виходячи із своїх інтересів, діти разом з учителем проектують вирішення будь-якого практичного завдання. Матеріал різних навчальних предметів групується навколо комплексів-проектів. Навчальне проектування орієнтоване, перш за все, на самостійну діяльність учнів: індивідуальну, групову або колективну, яку учні виконують упродовж певного часу [5, 94].
Науковець В. Нечипоренко у своєму дисертаційному дослідженні описує питання проектування інноваційного розвитку спеціального закладу як відкритої соціальноосвітньої системи, де розгорнуто описані компетенції учнів: навчання впродовж життя, соціальні, сімейно-побутові, комунікативні, інформаційні, політико-правові, професійнотрудові, полікультурні, культурно-дозвіллєві та екологічні. У Хортицькому центрі зазначені компетенції описані і реалізовані не ізольовано, а системно - в межах цілісної моделі компетентного випускника закладу, де проектування і проектне навчання $\epsilon$ важливою складовою [10]. Таким чином, проектування впливає на систему навчання у межах цілого начального закладу, а проектне навчання сприяє формуванню професійних компетенцій.

Науковці 3 різних країн, які активно використовували метод проектів на практиці, зазначають, що він $є$ ефективним у навчанні фахівців різних рівнів підготовки і його доцільно використовувати як доповнення до інших видів навчання з метою підвищення рівня знань, вмінь, навичок.

Зважаючи на наш теоретичний аналіз, ми підійшли до важливого питання - “проектна діяльність”, “творча проектна діяльність”, яке є суттєвим для нашого дослідження.

О. Коберник тлумачить проектну діяльність як специфічний вид діяльності, спрямований на створення суттєво нових продуктів, які $\epsilon$ результатом творчих пошукових зусиль особистості або колективу $[7,14]$.

Н. Яковлева розглядає проектну діяльність як обмежену в часі діяльність, представлену у вигляді заходів, спрямованих на вирішення соціально значущої проблеми і досягнення певної мети, що передбачає отримання очікуваних результатів шляхом вирішення пов'язаних з метою завдань, забезпечену необхідними ресурсами і керовану на основі постійного моніторингу діяльності та їі результатів з урахуванням можливих ризиків $[15,14]$.

I. Шевченко надала розгорнуту характеристику якостей, які формує проектна діяльність у студентів: навички самостійної орієнтації у навчальній, науково-методичній та довідковій літературі, вчить добувати необхідну інформацію самостійно; активно розвиває основні види мислення; сприяє психічному розвитку; робота 3 “неподатливим матеріалом" зміцнює їхню емоційно-вольову сферу; сприяє розвитку інтелектуальних здібностей, вчить мислити від абстрактного до конкретного; залучає студентів до реальної самоосвіти; сприяє інтеріоризації - 
переходу від зовнішніх дій до внутрішнього плану, та екстеріоризації - переходу внутрішніх дій до зовнішніх, тобто їх трансформації; допомагає студентам усвідомлювати себе творцями своєї діяльності; посилює позитивну мотивацію навчання, бо проект вибирається та реалізується на основі власних інтересів, потреб та можливостей; формує творче системне мислення; привчає студентів до цілепокладальної діяльності, яка $є$ головним компонентом перетворення інформації, енергіï, самого себе; сприяє формуванню культури ділового спілкування, умінню аргументовано захищати свої позиції; посилює уяву, яка є значним стимулом для народження нових ідей, пошуку альтернативних рішень, їх аналізу та синтезу, як основи інноваційного мислення; формує внугрішній план дій та реалізує його на практиці $[14,257]$.

Аналізуючи навчальні посібники 3 проектування можна відзначити, що проектна діяльність включає в себе низку етапів (умовних): пошуковий; аналітичний; практичний; презентаційний та контрольний, що в загальних рисах відповідає класифікації етапів: перший етап - актуалізація знань, прояв зацікавлення до теми, визначення мети вивчення конкретного матеріалу, другий етап - осмислення нової інформації, критичне читання та письмо, третій етап роздуми або рефлексія, формування власної думки стосовно навчального матеріалу, четвертий етап - узагальнення й оцінка власної діяльності [1].

У процесі творчої проектної діяльності у студентів формуються уміння та навички проектування майбутньої педагогічної діяльності, здатність до нетипового розв' язання поставлених задач, творчо-креативне мислення, розвиваються комунікативні здібності до співпраці й роботи у колективі - колективної діяльності, що дозволить майбутнім учителям, здійснювати педагогічну діяльність на високому професійному рівні [3, 38].

Активні дослідження, що дали позитивний результат використання проектної діяльності (творчої проектної діяльності), відобразились у роботах С. Астрейко, Ю. Кузьменко, М. Курача, О. Омельчука, І. Самаркиної, А. Шевченко, пов'язаних з формуванням професійних якостей, компетентності, компетенцій у підготовці учителів та фахівців (учителів технологій, графічних дизайнерів, дизайнерів одягу). На думку науковців, педагогічна теорія і практика мають обов'язково включати такий компонент навчання педагогів, як проектна діяльність, що значно підвищує професійний рівень майбутніх учителів.
Отже, наукова спільнота розділяє твердження, що поняття проект, метод проектів, проектна технологія, проектне навчання, проектна діяльність (творча проектна діяльність) є пов'язаними між собою визначеннями. Проектна діяльність створює не лише умови для набуття і відпрацювання певних знань та навичок, а й позитивну атмосферу під час самого процесу навчання. Саме тому метод проектів буде ефективним у формуванні поваги i доброзичливого ставлення майбутніх учителів образотворчого мистецтва до своєї професії, що $\epsilon$ обов'язковою умовою для сучасного учителя.

Таким чином, нами було проведено теоретичний аналіз виникнення та розвитку методупроектів, понять “проект”, “проектування”, “проектна технологія”, “проектне навчання”, “проектна діяльність”, їх значення для педагогічної практики, частково розкрито поняття “творча проектна діяльність”. Узагальнюючи матеріали нашого дослідження, можна дійти висновку, що у сьогоденні метод проектів, проектна діяльність студентів $є$ актуальним і перспективним видом навчання, тому що створює умови для розкриття творчого потенціалу студентів, підвищення їх мотивації, сприяє отриманню необхідних умінь та знань, розвитку їх інтелектуальних здібностей та формуванню професійної компетентності як конкурентоспроможного фахівця XXI століття. Проектна діяльність майбутніх учителів образотворчого мистецтва забезпечить набуття професійних соціально значущих знань, умінь та навичок, що відповідає сучасному запиту на освіту та парадигмі особистістно-орієнтованого навчання, тому що саме ці знання і вміння дають змогу молодим фахівцям навчатися упродовж життя та успішно реалізуватися у професійній діяльності. На основі аналізу було обгрунтовано, що проектна діяльність є дієвим засобом формування професійної компетентності майбутніх учителів образотворчого мистецтва у сьогоденні та має велике значення для педагогічної науки, тому вимагає додаткових теоретичних і практичних досліджень даного питання.

\section{ЛІТЕРАТУРА}

1. Безпалько О. В. Соціальне проектування навч. посіб./О.В.Безпалько;Київ. ун-тім.Б. Грінченка, Ін-т психології та соц. педагогіки. - К.: [б. в.], 2010. - $127 \mathrm{c}$.

2. Гитман Е. Проект в образовательной области “Технология” Е. Гитман, М. Гитман // Школьные технологи. - 2002. - №6. - С. 136 137. 


\section{ПРОЕКТНА ДІЯЛЬНІСТЬ ЯК ЗАСІБ ФОРМУВАННЯ ПРОФЕСІЙНОӤ КОМПЕТЕНТНОСТІ МАЙБУТНІХ УЧИТЕЛІВ ОБРАЗОТВОРЧОГО МИСТЕЦТВА}

3. Давидова С. В. Роль творчих проектів у формуванні професійної компетентності сучасних учителів / С. В. Давидова. // Матеріали III міжнародної науково-практичної конференції "Педагогікав системігуманітарногознання"(м. Одеса, 8-9 вересня 2017 року). Херсон: Видавничий дім "Гельветика", 2017. - С. 36-39.

4. Закон України "Про загальну середню освіту” [Електронний ресурс]. - Режим доступу до ресурсу: http://osvita.ua/legislation/law/2232/.; Прийняття від 05.09.2017. Набрання чинності 28.09.2017.

5. Ізбаш С. С. Реалізація творчих проектів у навчальному процесі сучасної школи / С. С. Ізбаш // Науковий вісник Мелітопольського державного педагогічного університету. Серія: Педагогіка: Зб. наук. статей / Ред. кол.: I. П. Аносов (голов. ред) та ін. - Мелітополь. - 2010. - Вип. 5. - С. 92-97.

6. Інтерактивні технології навчання: теорія, практика, досвід. Метод. посібник / Авт. укл.: О. Пометун, Л. Пироженко. - К.: АПН, 2002.

7. Коберник О. М. Проектна технологія: можливості застосування в освіті / О. М. Коберник // Педагогіка вищої та середньої школи. - 2012. - №. 36. - С. 11-18.

8. Курач М. С. Теоретичні і методичні засади навчання художнього проектування майбутніх учителів технологій: дис. на здобуття наук. ступеня докт. пед. наук: 13.00.02 “Теорія i методика навчання" / М. С. Курач - Київ, 2016. $478 \mathrm{c}$.

9. Любчак Н. М. Проектні технології: сутність та особливості використання у навчальному процесі // Вісник Чернігівського національного педагогічного університету. Серія: Педагогічні науки. - 2014. - №. 122. - С. 144-150.

10. Нечипоренко В. В. Теоретичні і методичні засади навчально-реабілітаційної діяльності спеціального закладу як відкритої соціальноосвітньої системи: дис. на здобуття наук. ступеня доктора пед. наук: 13.00.03 “Коррекционная педагогика" / В. В. Нечипоренко. - К., 2013. $456 \mathrm{c}$.

11. Савченко Л. О. Проектна діяльність в практиці вищої педагогічної школи [Електронний pecypc] / Лариса Олексіївна Савченко // Society for Cultural and Scientific Progress in Central and Eastern Europe Budapest. - 2013. - Режим доступу до ресурсу: http://scaspee.com/all-materials/11.

12. Слободяник О. В. Аналіз поняття “проект”, "проектна технологія", “педагогічне проектування" у дослідженнях зарубіжних та вітчизняних науковців / О. В. Слободяник // Наукові записки. Серія: Проблемиметодики фізико-математичноїі технологічної освіти. - 2015. - Т. 3. - №. 7. - С. 234-243.
13. Шаров С. В. Самостійна робота як умова формування професійної компетентності майбутніх фахівців / С. В. Шаров // Сучасні тенденції розвитку української науки: матеріали Всеукр. наук. конф.(21 -22 липня 2017 р.,м. ПереяславХмельницький). - Переяслав-Хмельницький, 2017. - №. 5. - С. 35-38.

14. Шевченко I. Педагогічне проектування та його складові / I. Шевченко // Наукові записки [Кіровоградського державного педагогічного університету імені Володимира Винниченка]. Сер.: Педагогічні науки. - 2010. - №. 91. - С. 256260.

15. Яковлева Н. Ф. Проектная деятельность в образовательном учреждении [Электронный ресурс] учеб. пособие. - 2-е изд., стер. - М.: ФЛИНТА, 2014. - 144 с.

\section{REFERENCES}

1. Bezpalko, O. V. (2010). Sotsialne proektuvannya [Social designing tutor]. Kyiv: Znannia. [in Ukrainian].

2. Gitman, E. \& Gitman, M. (2002). Proekt v obrazovatelnoy oblasti "Tehnologiya" [Project in the field of technology “Technology”]. School Technology, no.6, pp.136 - 137. [in Russian].

3. Davydova, S. V.(2017). Rol tvorchykh proektiv u formuvanni profesiinoi kompetentnosti suchasnykh uchyteliv [The role of creative projects in shaping the professional competence of modern teachers]. Materialy III mizhnarodnoi naukovo-praktychnoi konferentsii "Pedahohika v systemi humanitarnoho znannia” (m. Odesa, 8-9 veresnia 2017 roku) Proceedings of the 3rd international scientific-practical conference "Pedagogy in the system of humanitarian knowledge”. (pp. 36-39). Kherson: Vydavnychyi dim "Helvetyka" [in Ukrainian].

4. Zakon Ukrainy "Pro zahalnu seredniu osvitu" (Pryiniattia vid 05.09.2017 ). [Law of Ukraine "On General Secondary Education"]. osvita.ua. Retrieved from http://osvita.ua/legislation/law/2231/ [in Ukrainian].

5. Izbash, S. S. (2010). Realizatsiia tvorchykh proektiv u navchalnomu protsesi suchasnoi shkoly [Realization of creative projects in the educational process of modern school]. Anosov I. P. (Eds.) Naukovyi visnyk Melitopolskoho derzhavnoho pedahohichnoho universytetu - Scientific herald of Melitopol State Pedagogical University. Series: Pedagogy: Collection of Sciences Articles, vol.5, pp.92-97 [in Ukrainian].

6. Pometun, O. \& Pyrozhenko, L. (Eds.). (2002). Interaktyvni tekhnolohii navchannia: teoriia, praktyka, dosvid. Metodychnyi posibnyk [Interactive Learning Technologies: Theory, Practice, Experience. Methodical manual]. Kyiv: APN [in Ukrainian]. 
7. Kobernyk, O. M. (2012). Proektna tekhnolohiia: mozhlyvosti zastosuvannia v osviti [Design technology: the possibilities of application in education]. Pedagogy of higher and secondary schools,no. 36, pp.11-18. [in Ukrainian].

8. Kurach, M. S. (2017). Teoretychni i metodychni zasady navchannia khudozhnoho proektuvannia maibutnikh uchyteliv tekhnolohii [Theoretical and methodological principles of training of artistic designing of future technology teachers]. Candidate's thesis. Kyiv. [in Ukrainian].

9. Liubchak, N. M. (2014). Proektni tekhnolohii: sutnist ta osoblyvosti vykorystannia u navchalnomu protsesi [Design technologies: the essence and peculiarities of use in the educational process]. Bulletin of Chernihiv National Pedagogical University. Series: Pedagogical Sciences, no.122, pp.144-150. [in Ukrainian].

10. Nechyporenko, V. V. (2013). Teoretychni i metodychni zasady navchalno-reabilitatsiinoi diialnosti spetsialnoho zakladu yak vidkrytoi sotsialno-osvitnoi systemy [Theoretical and methodical principles of educational and rehabilitation activity of a special institution as an open social-educational system]. Candidate's thesis. Kyiv. [in Ukrainian].

11. Savchenko, L. O. (2013). Proektna diialnist v praktytsi vyshchoi pedahohichnoi shkoly [Project activity in the practice of higher pedagogical school] Society for Cultural and Scientific Progress in Central and Eastern Europe Budapest. Retrieved from http:// scaspee.com/all-materials/11 [in Ukrainian].

12. Slobodianyk, O. V. (2015). Analiz poniattia "proekt", "proektna tekhnolohiia", "pedahohichne proektuvannia" u doslidzhenniakh zarubizhnykh ta vitchyznianykh naukovtsiv [Analysis of the concept of "project", "design technology", "pedagogical design" in researches of foreign and domestic scientists]. Proceedings. Series: Problems of methodology of physical-mathematical and technological education, (vols. 3), no.7, pp.234-243 [in Ukrainian].

13. Sharov, S. V. (2017). Samostiina robota yak umova formuvannia profesiinoi kompetentnosti maibutnikh fakhivtsivy [Independent work as a condition for the formation of professional competence of future specialists]. Suchasni tendentsii rozvytku ukrainskoi nauky: materialy Vseukrainskoi naukovoi konferentsii - Contemporary trends in the development of Ukrainian science: Proceedings of the All-Ukrainian Scientific Conference no. 5, (pp. 3538). Pereiaslav-Khmelnytskyi. [in Ukrainian].

14. Shevchenko, I. (2010). Pedahohichne proektuvannia ta yoho skladovi [Pedagogical design and its components]. Proceedings. Series: Pedagogical Sciences, no.91, pp.256-260. [in Ukrainian].

15. Yakovleva, N. F. (2014). Proektnaia deiatelnost $\mathrm{v}$ obrazovatelnom uchrezhdenyy [Project activity in an educational institution]. Moscov: FLYNTA [in Russian].

Стаття надійшла до редакції 29.03.2018

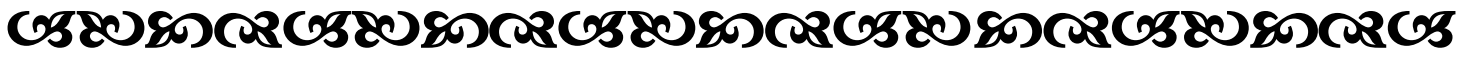

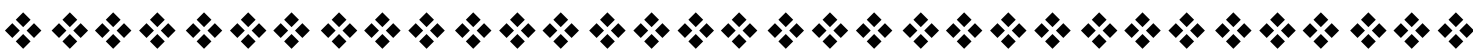

"ТІи робии найқращу $і$ для тебе рятівну справу, коли твердо ступаєи по иляху доброго глузду".

Тригорій Сковорода

ураӥнський фіхософ, поет, педагог

"Ефеективність навчання, його гуманістична сутність зумовлюються в периу чергу пробесіоналізмом і висоқою технологічною культурою педагога".

Василь Сухомлинський

уқрайнсьжий педагог, публіщист, письменник

"Жбоб відқрити перед учнями іскорку знанъ, учителю треба ввібрати море світла, ні на хвилю не відходячи від променів вічно сяючого сония знань людської мудрості”.

Василь Сухомлинський

украӥнський педагог

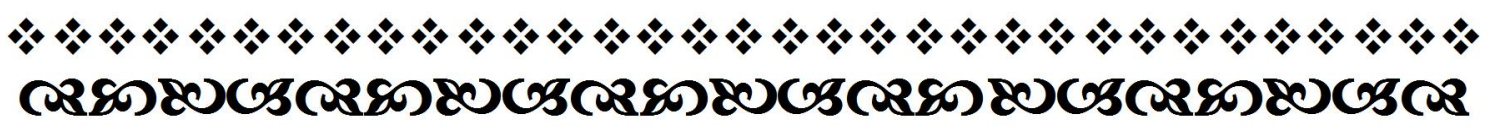

Молодь і ринок №5 (160), 2018 